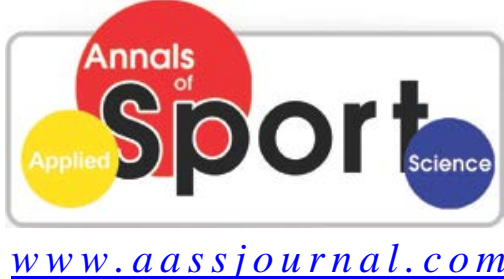

ISSN (Online): $2322-4479$

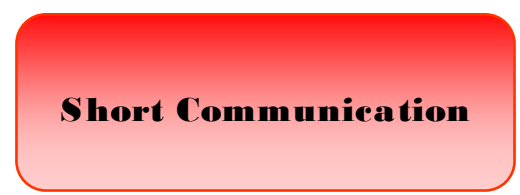

Received: $12 / 07 / 2014$

Accepted: 22/12/2014

\title{
Social Development of Students Participating in Physical Activity and Computer Games
}

\section{${ }^{1}$ Saadi Sami*, ${ }^{1}$ Sadigh Mahmoudi, ${ }^{2}$ Sarhad Aghaei}

1. Department of Physical Education and Sport Sciences, Marivan Branch, Islamic Azad University, Marivan, Iran.

2. Iranian Ministry of Education, Education Office, Paveh, Iran.

\section{ABSTRACT}

The purpose of this study was to compare the participation in physical activity and computer games on the social development of students. The population of this research was made up entirely of male students from secondary schools in the city of Marivan (mean age of 13.5 years). Among them, 300 were selected purposively (150 athletes, 150 computer games players). In order to collect the information, Weitzman's social development scale was used. For the statistical analysis of data, $\mathrm{n}$ independent t-test with a significance level $(\mathrm{P}<0.05)$ was used. Overall, the findings of this study suggest that the physical activity group has a higher social development than computer games group.

Key Words: Social Development, Students, Physical Activity, Computer Games.

Corresponding Author: 


\section{INTRODUCTION}

Social development is a balanced set of social skills and learned adaptive behaviors that enables an individual to interact well with other people, react positively and avoid behavior that has negative consequences. Cooperation, responsibility, empathy, selfcontrol and self-reliance are considered to be components of social development (1). It is assumed that children without social development and required skills are unable to perform their duties while interacting with others (2).

A child's game is a serious thing that happens in its mind, which is why its continuation is important, rather than the game itself, or its result. A child wants to play and is not looking for the result of the game. Basically, the game is an activity that its process is important, not its result, and this is the main feature of a game (3). Nowadays, the playing of computer games has replaced traditional games.

Computer games began with Pong in 1972 (a table tennis computer game). Improving the quality and variety of this games caused increasingly fast spreading of games in the media and in society, particularly among adolescents (4). Computer games can have positive effects, such as the development of personality and behavior, talent growth, creativity development, attention and precision training, increasing IQ, expanding the outlook on the world, strengthening artistry, complex conceptual education, culture communication, etc. (5). Stansbury (2004) found that participation in sports has a positive effect on the development of leadership and interpersonal skills of athlete students (6). Since these games are the second most common form of entertainment after the television, those opposed to these games emphasize their negative effects, which include addiction to the games, increased expression of anger and aggression, spending a lot of money to buy them, and other negative physical and mental effects. It can be pointed out that the effect of said damage is much more than increased hand - eye coordination and other positive aspects (7). Colwell and Payne (2000) in the study on 204 students of 10-14 years old, showed that although there was no direct relationship between social isolation and the games, there was a direct connection between aggressions and playing the computer games (8). Goldstein (2006) reported some of the possible applications of computer games as follows: using computer games to measure and evaluate the performance, using computer games to practice cognitive and perceptual skills, regulation of physiological and biological indicators, and nourishment a sense of cooperation, and the use of computer games for entertainment (9).

Socialization and development of social skills, which start from the moment of birth, are affected by several factors, including the participation in sporting activities. The social function of physical education and sports education on the development and consolidation of social relations is a functional and basic infrastructure that has significant effects on the whole structure of society, social groups and individuals' relationships (10).

Participation in sports activities helps children's social behavioral development, which is necessary for their compatibility with the world around them, and it moves them towards socially acceptable and desirable criteria (11). In contrast, children who are not exposed to physical experiences are less likely to learn social skills. So if an opportunity to practice and experience is not provided for them, they likely lose their interest and become dissociable (12).

Games for children, even if social opportunities exist, remain asocial (13). Singer (2009) reported that sports and group activities, increase social skills such as 
responsibility, problem-solving skills, improved interpersonal relationships, decision making and the social development of the students (14). Besides, team sports, with mutual roles that relate to each other in a realistic way, inspire self-confidence and self-control and a decrease in the feeling of boredom and fatigue (15). In other words, sports team activities are effective on expression, creativity, curiosity and selfcontrol (16). The results of Atashi (2008) showed that social maladjustment of athletic students is less than social maladjustment of non-athletic students (17).

Petitpas et al. (2004) found that sports and after school activities give a suitable base for the growth of ingenuity and a sense of selfefficacy in adolescents and enhances their communication capabilities (18).

Therefore, with regard to the growth of computer games in this age of communication, and the effect of participation in sports activities on social development, the researcher, with regard to the purpose of the survey, seeks to compare the effects of participation in sports activities and computer games on the social development of students.

\section{MATERIALS AND METHODS}

Participants. The population consisted entirely of male secondary school students in the city of Marivan in the academic year of 2007-8. The research sample consisted of 300 students (150 athletes, 150 computer games players) that were selected using targeted sampling. The criterion of the people in the computer games group was computer game experience of at least three days per week over the past six months. The athletes group included those who, during the same period had no experience in this field, but instead had regular physical activity.

Motor skill competence. In order to collect information, the Witsman social development scale was used. This test is used to measure the social development of those aged between 13 and 18 years. It was provided by Weitzman. The reliability of this scale in Iran is estimated by Naziri from 0.81 to 0.85 . The validity of the questionnaire form was approved and implemented by the questionnaire producer on students aged 13 to 18 . In the present study, the reliability coefficient for the scale was 0.88. The test had 27 questions, each with three or four options that measure independence, responsibility, predictability, moderation, hope, optimism, humor and wit. Each correct answer is given a score, otherwise zero, and the scores are placed between 0 and 25 (19).

Statistical Analysis. descriptive statistics were used to determine the mean, standard deviation and the independent t-test was used to compare groups' means. All operations of this research were done using computer software and SPSS13. Statistical significance was set at $\mathrm{P}<0.05$.

\section{RESULTS}

Descriptive indices of variables and t-test results are given in Table 1 . The findings show that the athletic group has a higher social development than the computer games group. According to Table 1, the difference between the two groups of athletes and computer games players is significant $(\mathrm{p}<0.001)$.

Table 1. Social development descriptive indices of students in groups of athletes and computer games

\begin{tabular}{ccccc}
\hline Group & $\mathrm{N}$ & Mean \pm SD & $\mathrm{t}$ & $\mathrm{p}$ \\
\hline athletes & 150 & $16.1 \pm 2.3$ & \multirow{2}{*}{3.2} & \multirow{2}{*}{$0.001^{*}$} \\
Computer games & 150 & $15.1 \pm 2.8$ & & \\
\hline
\end{tabular}

$*(\mathrm{p}<0.05)$ 


\section{DISCUSSION and CONCLUSION}

The purpose of this study was to compare the participation in sports activities and the playing of computer games with regard to the social development of students.

The results of this study showed that the students that take part in physical activities have a higher social development than the students that play computer games. The exercise helps the increase of social skills and the prevention of social conflicts (17, 20). In sport and group activities, people learn to help others, consistency with the group, cooperation, forgiveness, dedication, independence, self-confidence, respecting the law, and friendship with others. In general, individuals' social growth will be developed through group activities including team sports. Exercise by communicating, modelling, reinforcing feedback, social and communication skills, preparation and motivation, emotional development, enhancing adaptability, and self-esteem effect the reinforcement of social development (21). Participation in sports and group activities causes an increase to social skills such as accountability, problemsolving skills, improved interpersonal relationships, decision-making and social development of students (20).

The results of this study are inconsistent with studies of Colwell and Payne (2000) showed that there is no direct relationship between social isolation and computer games (8). It can be said that most research carried out on the role of computer games in the social development of adolescents has been conducted on the role of computer games clubs that are a place for young people to come together and finally meet and interact with each other thus meaning there is little effect on social development. Computer games clubs are social places and centers to develop friendships. Besides, going to game clubs represents an important aspect of the social life of adolescents. These cubs are a place to meet others, learn their behaviour and how to behave toward them (22).

Aries et al. (2004), in a study of two groups of athlete and non-athlete students showed that athlete students in comparison with non-athlete students have better peopleoriented skills, extroversion, and self-report from their well-being and society (23). The effects of sporting and group activities on social growth of students are consistent with this study's results $(15,16)$. According to the results of this study, provision of sports facilities in and out of schools and limiting the time students play computer games by parents and school officials are important requirements for the social development of students.

\section{APPLICABLE REMARKS}

- Involvement in physical activity can improve social development of students than computer games.

\section{REFFRENCES}

1. Gallahue DL, Ozmun JC. Understanding Motor Development: Infants, Children, Adolescents, Adults. 4th ed: McGraw-Hill College; 2000.

2. Beelmann A, Pfingsten U, Lösel F. Effects of training social competence in children: A meta-analysis of recent evaluation studies. Journal of Clinical Child Psychology. 1994;23(3):260-71.

3. Iranian Ministry of Culture. Cultural consequences of toys. 3rd ed. Tehran, Iran: Culture and Knowledge Publication; 2001 [Book in Farsi]. 127 p.

4. Morrison M, Krugman DM. A Look At Mass and Computer Mediated Technologies: Understanding the Roles of Television and Computers in the Home. Journal of Broadcasting \& Electronic Media. 2001;45(1):135-61. 
5. Golrokhi S. Toys role in the transmission of culture to children. Cultural consequences of toys; Bahman Cultural Home, Tehran, Iran: Iraninan Ministry of Culture; 1996 [Article in Farsi].

6. Stansbury S. Evaluating Academic Success in Student Athletes: A Literature Review. Concept. 2004;27.

7. Anderson CA, Bushman BJ. Effects of violent video games on aggressive behavior, aggressive cognition, aggressive affect, physiological arousal, and prosocial behavior: a meta-analytic review of the scientific literature. Psychological science. 2001;12(5):353-9.

8. Colwell J, Payne J. Negative correlates of computer game play in adolescents. British journal of psychology (London, England : 1953). 2000;91 ( Pt 3):295-310.

9. Goldstein J. Applied Research in Video Games Utrecht University, 2006 Mon., 10 April 2006. Report No.

10. Damirchilou M. The effectiveness of social skill training. Education. 1993;8(8):48-52 [Article in Farsi].

11. Aslankhani MA. Effect of physical education and sport in the development of students' social skills. Ornament of Sport. 2009;2(8):[Article in Farsi].

12. Haywood K, Getchell N. Life Span Motor Development 6th Edition. 6th ed: Human Kinetics; 2014. 448 p.

13. Payne VG, Isaacs LD. Human Motor Development: A Lifespan Approach. 8th ed: McGraw-Hill; 2012. 579 p.

14. Singer JL. Researching imaginative play and adult consciousness: Implications for daily and literary creativity. Psychology of Aesthetics, Creativity, and the Arts. 2009;3(4):190-9.

15. Ellis MJ. Why People Play. 3rd ed: Prentice-Hall; 1973. 173 p.

16. Shaffer D. Social and Personality Development. 6th ed: Cengage Learning; 2008. 608 p.

17. Atashi SH. Social adjustment of high school students athlete and non-athlete in Yazd city 2008.

18. Petitpas A, Van Raalte J, Cornelius A, Presbrey J. A Life Skills Development Program for High School StudentAthletes. The Journal of Primary Prevention. 2004;24(3):325-34.

19. Weitzman E. Growing up socially: American Printing House for the Blind; 1952. 65 p.

20. Singer JL, Singer DG, editors. Imaginative play in preschoolers: some research and theoretical implications. Proceedings of the American Psychological Association, Incorporated, for the year 1980; 1980; Montreal: American Psychologist.

21. Razavi SMH, Manani M, Amirnejad S, editors. Effects of a selected period of exercise training on social development and public health of male students. The Fourth Seminar on Mental Health of College Students; 2008; Shiraz, Iran: Shiraz University [Article in Farsi].

22. Gunter B. The Effects of Video Games on Children: The Myth Unmasked: Sheffield Academic Press; 1998. 172 p.

23. Aries E, McCarthy D, Salovey P, Banaji M. A Comparison of Athletes and Non-Athletes at Highly Selective Colleges: Academic Performance and Personal Development. Research in Higher Education. 2004;45(6):577602. 
تازههاى علوم كاربردى ورزش

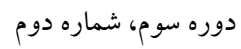

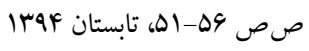

مقاله كوتاه

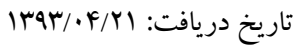

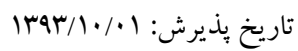

\title{
رشد اجتماعى دانش آموزان شركت كننده در فعاليتهاى ورزشى و بازى هاى رايانهاى
}

'سعدى سامى *' 'صديق محمودى، 'سرحد آقايى

\author{
ا. مربى گروه تربيت بدنى و علوم ورزشى، دانشگاه آزاد اسلامى، واحد مريوان، ايران. \\ r. دبير تربيتبدنى، آموزش و يرورش، ياوه، ايران.
}

جكيده

هدف از يزوهش حاضر، مقايسه رشد اجتماعى دانش آموزان شركتكننده در فعاليتهاى ورزشى و بازىهاى رايانهاى بود. جامعه آمارى

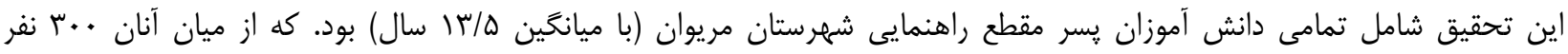
بصورت هدفدار انتخاب شدند (•ها نفر ورزشكار، •ها نفر بازيكن بازىهاى رايانهاى). به منظور جمع آورى اطلاعات از مقياس رشد اجتماعى وايتزمن استفاده شد. يافتههاى اين يزوهش نشان مىدهد كه گروه فعاليت ورزشى از رشد اجتماعى بالاترى نسبت به كروه بازىهاى رايانهاى برخوردارند. لذا دركيرى در فعاليتبدنى بيشتر از بازىهاى رايانهاى مىتواند رشد اجتماعى را بهبود بخشد. وازَّان كليدى: رشد اجتماعى، دانشآموزان، فعاليتهاى ورزشى، بازىهاى رايانهاى. 